\title{
A SYMPOSIUM ON THE APPOINTMENT, DISCIPLINE AND REMOVAL OF JUDGES
}

The Annual Meeting of the Canadian Bar Association, Banff, Alberta, August 30, 1971.

Members of a panel at the Annual Meeting of the Canadian Bar Association, 1971, suggest and analyze possible methods of improving the present process of selection and appointment as well as the disciplining and removal of judges. The Chairman, Mr. D. C. McDonald, outlines a proposal for a system of judicial appointments as suggested by Professor $E$. A. Tollefson in a recent article. From Professor Tollefson's proposal Mr. McDonald extracts several "possibilities" including an intensive training course for judges upon their appointment, periodic refresher courses for all judges and the extension and upgrading of the "research staffs" available to the courts. The Chairman goes on to compare and contrast the disciplinary provisions that are applicable to Supreme, District and Provincial Court judges. Panel member G. M. Stirling, Q.C., who has served on the National Committee on the Judiciary of the Cana. dian Bar Association, describes its function and method of operation and concludes that it is only a first step in the process towards an improved method of selecting the most competent and highly qualified judges. $M r$. Stirling suggests that a modified form of the "Missouri plan" could be followed in Canada. The plan would involve the setting up in every province of a standing independent commission "which would screen all qualified and available lawyers in the province and submit a limited number of names to the Minister of Justice" from which the Minister would make his selection. Panel member, W. H. Hurlburt, Q.C., also endorses an "appropriate adaptation" of the Missouri plan and goes on to suggest how the nominating commission might be constituted. With regard to the removal and disciplining of judges, Mr. Hurlburt approves of the concept of a Judicial Council as set up by an amendment to the Judges Act (S.C. 1970-71-72 c. 55) but suggests that if the Council is to operate efficiently it must have an office and administrative staff. Panel member F. C. Muldoon, Q.C., submits that although a wholly political process of selection and appointment of judges has certain defects, "political input into the process is proper and ought not to be eliminated." Mr. Muldoon approves of the concept of the nominating commission as proposed by Mr. Hurlburt but disagrees with the suggested composition of the body. The Honourable E. D. Fulton, P.C., Q.C., opposes a system where the Minister must make an appointment from a list of names proposed by a non-governmental body. He points out that such a body would have no real responsibility in the event that an appointment turned out badly and that therefore "the prime responsibility and initiative must remain with the approving authority." Further, Mr. Fulton notes that politics are not confined to governments or political bodies, and that there would be no benefit in substituting the politics of a body that is not responsible to the general electorate for the politics of one that is. The Honourable Sir Robert Megarry concludes the symposium by outlining the formal details and hidden realities involved in appointments to the Bench in England. Sir Robert states that "the judicial quality is something that a man has or has not got" and therefore he attaches very little importance to a system of formal training for judicial office. He goes on to outline several stages in the part played by politics in appointments to the Bench, and points out that politics have ceased to play an important part in appointments to the Bench in England.

The panel consisted of the following:

Chairman: Mr. D. C. McDonald, Barrister and Solicitor, Messrs. McCuaig, Desrochers, Edmonton, Alberta.

Members: Mr. G. M. Stirling, Q.C., Barrister and Solicitor, Messrs. Stirling, Ryan, Goodridge, Caule, Gushue \& Goodridge, St. John's, Newfoundland. 
Mr. W. H. Hurlburt, Q.C., Barrister and Solicitor,

Messrs. Hurlburt, Reynolds, Stevenson \& Agrios,

Edmonton, Alberta.

Mr. F. C. Muldoon, Q.C., Barrister and Solicitor,

Chairman, Manitoba Law Reform Commission,

Winnipeg, Manitoba.

The Honourable E. D. Fulton, P.C., Q.C., Barrister and Solicitor,

Messrs. Fulton, Cumming, Bird, Richards,

Director, British Columbia Law Reform Commission,

Vancouver, British Columbia.

The Honourable Sir R. E. Megarry,

Judge of the Chancery Division,

High Court of Justice,

London, England.

\section{THE CHAIRMAN}

My own serious interest in the subject before us today arose several years ago when I was president of a provincial political association being that of the party in power federally. Those of us in Edmonton who wielded apparent power were determined to ensure that, within the existing system, such recommendations for appointments as flowed to the Minister of Justice from any responsible party officials did so after due and often detailed consideration by a co-ordinating committee of constituency association presidents and the like. It was not a bad attempt to sift and channel opinions through people who had, after all, been elected to positions of responsibility within the party, and it represented an attempt to operate the system democratically. During that period our views were remarkably effective with Ministers who preceded Mr. Turner as Justice Minister, because they were an attempt at rationality, given the rules of the game. At least one unsavoury experience during that period caused me to resolve to make an effort at some time in the future to further the cause of reform of the system of selection.

Around that time the longstanding struggle of some prominent figures in the Canadian Bar Association bore fruit with the creation in 1966 of the National Committee on the Judiciary and the announcement in 1967 by Mr. Trudeau, then Minister of Justice, that he had been consulting the Committee. Mr. Turner has continued this practice and deserves full credit for doing so. However, the manner in which that Committee works in practice and even its membership have, for five years, been a mystery. This mystery will be removed today, most informatively, by Mr. Stirling.

After five years I do not consider it unreasonable to provoke this Association, and our political leaders, into considering further reform. Let us not stand still in the search for better justice in all respects. Another reason for keeping the spotlight on the question of selection of judges is that, if there is in the future to be a constitutionally entrenched Bill of Rights, the influence of judges on our politico-social development will be even more significant than it has been in the past, and therefore their qualifications are even more important. When word of this panel reached certain quarters it was suggested to me that matters of this kind ought not to be discussed in public, but only between gentlemen, in private. I disagree-the more so because laymen are prepared to discuss these matters publicly.

I am sure it is not necessary among lawyers to say it, but lest there 
be any misunderstanding, I wish to say that in organizing this panel, the Alberta Subsection on Constitutional Law in no way intends to imply that the quality of judges in Alberta or in Canada as a whole is low. There are, of course, many judges of outstanding ability, and by and large the Bench is very good. This does not mean it could not be better. To the extent that the process of selection and appointment may depend on happenstance and irrelevancies, the question is whether a further improved system of selection could reduce the chances of mistaken appointments. Similarly, to discuss possible improvements in the training of judges does not imply that at present they are "untrained". Finally, to discuss methods of discipline and removal of judges does not imply that disciplinary problems arise frequently. In other words, to ask whether society can be improved is not necessarily to condemn existing social mechanisms.

\section{The Training of Judges}

Until recently in Canada there has never been any suggestion that judges should go through any form of training. Practising lawyers receive the call from the Minister of Justice, and in the space of a week or two they are expected to be sworn in and assume judicial duties. No doubt the wise appointee seeks advice from experienced judges, particularly in the first months, and no doubt, many experienced judges compare notes with each other during the trial of special cases, and generally. But certainly, there is no organized form of "continuing judicial education", other than the experience gained from case to case.

As far as organized judicial exchanges of views are concerned, a development to be noted is the annual conference of Canadian Chief Justices. Another recent development is the Canadian Judicial Conference where each year two judges selected from each province attend a week long meeting. These are encouraging trends for which credit is due to the Minister of Justice and others responsible for taking these initiatives, and it would be useful to hear some detail as to how these meetings work, and what their advantages and disadvantages are. Unfortuantely, this cannot be the place or time to do so, as the panel has a rather full agenda. Another quite different development is the annual program of intensive French-language training at Quebec City for judges from the common law provinces. As with the Chief Justices' Conference, this programme is financed by the Federal Department of Justice. It is a long way from these developments to any well-financed, well-organized programme of judicial training, but their significance may lie in the precedent they set for the involvement of the Department of Justice in continuing training for judges. If a programme can be developed in the interests of judicial bilingualism, why not in the interests of judicial expertise?

In an article in the University of Toronto Law Journal this year, ${ }^{1}$ Professor E. A. Tollefson of the University of Saskatchewan discusses the question of judicial training. Incidentally, he has this month joined the Department of Justice and consequently is not at liberty to participate in this panel. His thesis is that the introduction of a system of judicial appointments based on merit only would not achieve its desired objective of a greatly improved quality of justice in Canada. He doubts

1 The System of Judicial Appointments: A Collateral Issue, (1970) 31 U.T.L.J. 162. 
that Canadian lawyers, and consequently Canadian judges, are as learned in the law as they might be, and regards Canadian judgments as unduly influenced by mechanical jurisprudence. He suggests three practical changes which: ${ }^{2}$

... would be of great assistance in up-grading the quality of judicial knowledge in Canada. They are: specialization within the courts; the provision of research staff to assist superior court judges; and a greater use of outside experts.

Professor Tollefson also questions the ability of Canadian judges to analyze the legal problem and synthesize a clear and logical conclusion. He is concerned in this respect that some of our judges have, while in practice, been pedestrian form-following solicitors, and that even those who have been barristers may lack the analytical and communicative skills required of a judge. He doubts that the partisan habits of a barrister necessarily prepare him to be a non-partisan judge. (This problem, of course, is not peculiar to Canada.)

Professor Tollefson observes that when the Canadian Judicial Conference was established in 1969, then Minister of Justice, Mr. Turner said:3

... the quality of our judges determines the quality of our justice and one of the most important variables in the quality of our judges is the nature and extent of judicial training.

As I have already observed, and as does Professor Tollefson, this may serve as a precedent for the establishment of a judicial training program. Incidentally, he also states:4

The Canadian Bar Association could play a major role in stimulating discussion among its members and in making proposals to the ministers of justice with respect to judicial reform. However, whether we would be justified in expecting the Association to give aggressive leadership in this area is doubtful in view of the fact that conservatism and caution have been the hallmarks of its past actions.

\section{Professor Tollefson proposes that: 5}

Instead of the Minister of Justice merely naming a lawyer to one of the judicial vacancies, he would invite each year a few selected members of the Bars of each province to be candidates for judicial examinations. These examinations would be prepared and supervised by a committee composed of representatives of the Department of Justice, the Bench, the Bar, and the law teachers. The examinations would be designed to determine the strengths and weaknesses of the candidate's legal and practical knowledge. Only the more successful candidates would be granted admission to the judicial training program.

The judicial training program should involve a minimum of a year's instruction and in-service training tailored as closely as possible to the needs of the individual candidate. Every candidate should receive special training on topics such as legal analysis, directing juries, writing judgments, assessing damages, and sentencing. These are subjects which do not form a part of a lawyer's formal legal training, nor will he have gained expertise in them as a result of his practise; moreover, none of these areas is blessed with good textbooks which can be used as a reliable guide by the judge. In these areas in particular, the faculty in charge of the training program should not hesitate to break new ground. These areas have in the past been largely within the discretion of the individual judge. Along with standardization of the training of judges might go standardization of directions to juries; standardiza-

\footnotetext{
Id. at 164.

3 Id. at 170.

Id.

5 Id. at 170-171. Since this panel was presented, Mr. Justice Edson L. Haines, of the Ontario High Court of Justice, writing in (1971) Chitty's Law Journal 326, has made suggestions similar to some of those made by Mr. Tollefson. He suggests an institute for the judiciary, which would provide judges at all levels with an introductory immersion course and continuing education courses.
} 
tion of the form of judgments (as is the case in France); and standardization of sentences and awards of damages, with the aid of the computer. Every candidate should also be required to take a refresher course in subjects in which his results on the qualifying examinations indicate a deficiency. A candidate should show a particularly high degree of competence in procedure and evidence before being exempted from the obligation of taking refresher courses in these areas. In view of the increasing pressure for bilingualism in the courts, the program should also be designed to assure that all judges have a working knowledge of both official languages. In addition to classroom teaching and assignments, the program should include in-service training whereby a candidate would sit on various courts as an 'associate justice' with the power to participate in the proceedings but not to vote in the determination of the issue.

On the basis of their performance in the course, candidates would be appointed to the appropriate courts, either federal or provincial, as vacancies arose. Some candidates might not be appointed to a judicial post immediately, either because there were no suitable vacancies, or because their performance in the course was deficient in some material particular. The former could be used as relief judges-to fill in for judges who for one reason or another were unable to attend to their duties-or as supernumerary judges-to assist in the expeditious disposal of lengthy dockets, from time to time. Those candidates who had not completed the course satisfactorily, on the other hand, would be allowed a reasonable time to make up their deficiencies before being either posted or required to discontinue. It is assumed that the latter drastic action would be relatively rare if the initial selection and screening processes were done properly.

The training program would at first be compulsory for all new appointments, but as the program developed it should be compulsory for all judges to take refresher courses at specified intervals. Whether the student at the judicial school were a veteran judge taking a refresher course or a candidate for a judgeship, he or she should be paid a stipend commensurate with their experience, training and the high responsibility entrusted to judges by society.

Here it may be noted that in the most recent Hamlyn Lecture, according to a reviewer in the Law Quarterly Review, ${ }^{6}$ the retired English County Court Judge H. C. Leon (better known as Henry Cecil, the author) proposes that no one should be appointed a judge until he has demonstrated a proper judicial temperament by probationary service as a commissioner of assize or other temporary judge. He also suggests that every new judge should be warned by a senior colleague in some detail of the dangers of abuse of judicial power.

I doubt very much that the program proposed by Professor Tollefson is practical unless it is assumed that appointees to the bench of a province need not have been practitioners in that province. Such an assumption could not readily be made. If not made, then in all provinces except the two most populous ones it would be impossible to have even one or two judicial trainees named, as, depending on the death rate, it might take years for a vacancy to occur in the court. However, from Professor Tollefson's proposal I would extract and adapt the following five possibilities:

1. Upon the appointment of a judge (or a provincial magistrate), he should, during his first year, attend an intensive training course lasting, say, two months.

2. Every judge should be required, once every five years (for example) to attend a one-month refresher course.

3. The system of bright law graduates serving as law clerks should be expanded from its present use in the Supreme Court of Canada and its spotty usage elsewhere.

- Cecil, The English Judge at 76-77. 
4. In addition, each superior court should have a research staff of experienced lawyers to serve as senior law clerks to the court.

5. Specialization in the courts should be encouraged, but it is recognized that this is possible only in the more populous jurisdictions.

\section{The Disciplinary Provisions of the Amendments to the Judges Act ${ }^{7}$}

Many Canadian lawyers regret the continuing distinction between Supreme Court and District/County Court judges. I share that view. Consequently I regret the present law by which District/County Court judges can have their salaries cut off at the pleasure of the Minister of Justice. I regret that the proposed amendments to the Judges Act will leave this situation unaltered. The judicial responsibilities, in both criminal and civil matters, of those judges are not less in kind than those of Supreme Court judges, and their independence of the executive arm of the government should be equally assured. As regards Supreme Court judges, the amendments propose that upon the Canadian Judicial Council recommending the removal of a judge and that recommendation being accepted by the Governor General in Council, his salary is from that point cut off, even before Parliament has decided whether or not to accept the recommendation. In my view this provision is undesirable. It presumes the result of consideration of the recommendation by Parliament, and cuts the judge off from his salary for what may be an interminable time, since there is no statutory limit within which Parliament must accept or reject the recommendation.

The provisions of the Alberta Provincial Court Act ${ }^{8}$ should be noted. This Act establishes a Provincial Court Advisory Committee composed of a member of the Trial Division of The Supreme Court of Alberta, two provincial judges, one member of The Law Society of Alberta, and one other person, all of whom are to be appointed for three-year periods by the Lieutenant Governor in Council. Its disciplinary jurisdiction empowers it: ${ }^{9}$

... to receive, investigate and inquire into complaints respecting the lack of competence or misbehaviour of or neglect of duty by judges or the inability of judges to perform their duties.

The Committee has the powers of commissioners appointed under The Public Inquiries Act, and its inquiries are not to be public. ${ }^{10}$ After holding an inquiry, the Committee may reject the complaint, censure the judge, or recommend to the Attorney General the removal or retirement of the judge from office. If removal or retirement is recommended, one or more judges of the Supreme Court of Alberta will be appointed by the Lieutenant Governor in Council to hold an inquiry. If the recommendation of the Committee is affirmed, the Lieutenant Governor in Council may make an order of removal or retirement, and that order and the report of the inquiry must be laid before the legislature. ${ }^{11}$

Thus in Alberta it may be that Provincial Judges have a greater degree of independence from the executive than do federally appointed District Court Judges.

\footnotetext{
7 Bill C-243. An Act to Amend the Judges Act and the Financial Administration Act. Given Royal Assent October 6, 1971.

B.A. 1971, c. 86. The Alberta provisions are more comprehensive than those in the Ontario Provincial Courts Act, S.O. 1968, c. 103, as amended S.O. 1970, c. 38.

9 Id. s. 9(1)(b).

10 Id. ss. 9(2) and (3).

1 These provisions are found in $8.9(4)$ and s. 10.
} 


\section{REMARKS BY G. M. STIRLING, Q.C.12}

There is still some misunderstanding in the minds of some members of the Association as to the function of the National Committee on the Judiciary and I should make it clear to them at the outset that we have no part whatever in the selection or appointment of judges. By an arrangement made between the Association and the then Minister of Justice, this Committee was set up with the sole function of advising the Minister as to whether or not, in our opinion, a nominee was qualified for appointment to the Bench. I wish to make it quite clear that I have no authority to speak for the National Committee. Any views I may express are entirely my own.

I should explain the method of operation: The Minister submits to our Chairman the names of the parties that he is considering for appointment and these are circulated in a personal confidential manner to each member of our Committee. I cannot, of course, inform you as to the manner in which the other members operate, but I assume that they adopt the same procedure that I do-that is, that I contact, by long distance telephone, friends or acquaintances in the particular locality where the nominee practices-and they, in a confidential manner, give me their opinion as to the qualifications of that particular nominee. On the basis of the information that I receive, I then notify the Chairman that, as far as I can ascertain, the party in question is well qualified, qualified, or not qualified, as the case may be, for judicial appointment. In most instances, I enlarge a little upon the report that is made in respect of each individual. Where there is a serious divergence of views expressed by the members of the Committee, the Chairman invariably requests a reassessment. The chairman then correlates the information that he receives and advises the Minister.

As you will appreciate, the Minister is not bound to be guided by the advice of our Committee, although I believe in all but one or two cases he has done so. To the best of my knowledge, there was only one instance in which the Minister was not prepared to accept the views of our Committee, and in another case, an appointment was made without reference to us. In both of these instances, the Chairman brought the views of our Committee firmly to the attention of the Minister with, I believe, a salutary effect. Whether or not our Committee is serving a useful purpose may best be judged by the results to date. There may be conflicting views in this regard but, as far as I can ascertain, the Minister has been very happy to have the assistance and support of the Committee and it seems to me it must be of great assistance to him in reaching his conclusion, independently, without having to submit entirely to political or other pressures.

The members of the Committee have endeavoured to act carefully and dispassionately in obtaining their reports and have not been influenced by local or regional pressures. If the existence of the Committee does not prove to be a deterrent to unwarranted or frivolous nominations, I firmly believe that, at the very least, the Minister must realize that every submission will be fearlessly scrutinized and reported upon, and that, if he should persist in disregarding the views of the Committee, he would be open to serious criticism from this Association-which we

12 Mr. Stirling has served on the National Committee on the Judiciary of the Canadian Bar Association since 1967. 
persist in claiming to be a very influential body. None of us would be naive enough to think that the names that are submitted are not prompted, in most instances, by some political consideration. However, as far as we have been able to ascertain, most of the appointments made by the present Minister of Justice and his predecessor have been very favourably received.

Since its inception there have been several matters that the Committee has considered as to its method of operation. One proposal was that it should be divided into regional groups and that names of the nominees to be appointed in that particular area would be submitted to the members of the regional sub-Committee and the others would not be required to express any opinion. While certain members of the Committee were inclined to support this proposal, the majority felt that it would be unwise-as the national character of the Committee would be destroyed and it would lose something of its strength and also of the diversity of views. Another problem which was encountered was a certain amount of overlapping and duplication in the sense that members of the Committee from various parts of the country would be telephoning the same parties in a particular area. This was probably so when all of us would, naturally, be inclined to call some of our friends of the Canadian Bar Association. It was proposed that each member would list the parties that he used as contacts in the various towns and cities and that others would avoid calling these individuals. Here again, there was a majority decision against this proposal. It seems very obvious to me that the Committee would not be as likely to obtain frank and outspoken comments from the parties contacted, if they knew that every member of the Committee was aware of the individuals upon whom the others relied for the basis of their opinion. I have found the greatest cooperation from the parties that I have contacted across this country, because I am quite sure they felt that the information they gave me, and the opinions they expressed, were treated in confidence, and that no one-even the Chairman of the Committee-knew the source from which I obtained my own information.

While I am quite sure that no one here would suggest that the mere fact that a man is involved in politics, or has been a staunch supporter of a particular party, makes him unfit for judicial appointment, yet I have found, in many instances, that, where I have telephoned to an area in the course of the business of this Committee, my friends have said time and time again that, while the party mentioned is qualified for appointment, there are several far better lawyers in that area who are not being considered. This, obviously, raises the very important issue which no doubt will be discussed by other panelists-as to whether or not the time has come when a further effort should be made by this Association to urge that a different method of appointment of judges should be adopted.

Those of us who have had the opportunity of reading some of the material that has been published in the United States dealing with this same problem have, I am sure, been impressed by the success of what is known as the "Missouri plan" and it seems to me that a modified form of this procedure could very well be followed in Canada. It might be desirable to suggest that, in every province, a standing independent commission should be set up composed of a Judge of the Superior Court, as Chairman, with reputable senior lawyers and representative 
laymen forming the membership, who would screen all qualified available lawyers in the province and submit a limited number of names to the Minister of Justice, and that the Minister would have the final selection, but would be bound to appoint one of the men named by the Commission. This would not prevent the Minister from requesting the Commission to consider the parties that he would wish to appoint, for political reasons, but it would have to be definitely provided and understood that no judge would be appointed who was not on the final slate submitted by the Commission, or subsequently approved by it. This is not an entirely novel idea for, according to Professor Angus, a commentator in 1872, suggested:13

... should a vacancy occur on the Bench of the Superior Court in Montreal, for instance, let all barristers of over ten years' standing, practising in the district meet, and by a plurality of votes, suggest the names of six practising barristers to the Judges of the Superior Court there resident, who should be bound to select from the six names so suggested, three, which should be sent in to the Minister of Justice, who should thereupon appoint one of the three barristers whose names had been so received, to the vacant seat on the Bench.

The same matter has received the serious consideration of this Association from time to time without any great success.

The National Committee on the Judiciary was a step in the right direction and, I trust, has now proved its worth-but, it is only a beginning -a first step-and the Association should now press on to inaugurate the setting up of Provincial Commissions for the purposes that I have outlined. The prerogative of appointment still rests with the Crown, as represented by the Minister of Justice, but the "Missouri-type plan" should prove to be the best method of securing the most competent and highly qualified judges.

In this complex and technical world in which we are living and carrying on our professional activities, it becomes more and more evident that, with the mass of new legislation-both Federal and Provincial-it is impossible for one man to be conversant with current law dealing with every aspect that comes before the Courts. Training and continuing education for the judges are subjects that will require careful and more pressing consideration in the future and this meeting should be competent to make some practical proposals along these lines.

\section{REMARKS BY W. H. HURLBURT, Q.C. ${ }^{14}$}

\section{Appointment of Judges}

\section{(a) Selection of judges}

"The quality of our judges is the quality of our justice."15

The quality of the legal profession, the police, the law and even the quality of our Court houses also affect the quality of justice. But it is true that the quality of our justice depends upon the quality of our judges. We should, therefore, do everything possible to see that the person who becomes a judge is the one who will best perform the judicial function. The proposition here advanced is that the qualifications

\footnotetext{
13 Judicial Selection in Canada-The Historical Perspective, (1967) 1 Canadian Legal Studies 237.

14 The first part of Mr. Hurlburt's remarks are based on an earlier article by him, Appointment of Judges, (1968) 6 Alta. L. Rev. 175.

is Hon. Robert Leflar, as quoted by Hon. Tom C. Clark (formerly Assoclate Justice of the Supreme Court of the United States), (1969) 15 McGill L.J. 3.
} 
of those available should be investigated carefully and that the investigation should not be affected by any consideration other than fitness for the judicial function.

In practice, judges are appointed to the superior, district and county courts in the expectation that they will perform the judicial function well. The evidence, however, is that extraneous factors are also considered. It is an advantage to have deserved well of the political party which forms the Government of the day. It is an advantage to have the support of the right members of that party. It is not clear that the standards of the Minister of Justice and of the Cabinet have always been and will always remain as high as they are today. It should not be difficult to choose between a system of appointments which has regard only to merit and a system which has regard to merit and something else.

There is another consideration. Our judicial institutions can function only while they retain the confidence of the public. The judiciary can retain this confidence only while they are considered to be impartial and competent. We cannot assume that public confidence will survive the changing times:

We have been assuming, and not without good reason, that every accused and every
litigant has had faith in our judges' impartially and competence . . . However, in
recent years there has been a trend towards reduction in public confidence which
must be arrested and the old opinion restored.'
We have good judges-many are great ones. And so do you. But I ask you: 'Is every
appointment the best?' Does the system lend itself to the appearance of political
preference and manipulation? If so, it should be corrected. Even the appearance of
justice must be the best. If, through the system, some believe that politics is the pre-
dominating factor in the selection of judges, that is bad. We in the United States suffer
from the same problem and are endeavoring to correct it. Indeed there is a mighty
crusade in the United States today to correct such 'appearances'.17
If they [Judges] have a political, or other sinister appearance the integrity of the entire
system is tarnished and undermined. When it starts from politics it ends with politics
in the minds of the multitude, particularly the dissatisfied. We must avoid these con-
notations. The appearance of the judge and his staff must be above suspicion.

In the absence of a strong tradition to the contrary, the executive power tends to appoint judges from among its own supporters. For example, the American Bar Association Standing Committee on the Federal Judiciary reported in 1956 that "since the first administration of Grover Cleveland, no president has made less than $82.2 \%$ of his appointments from the ranks of his own party."19 In their appointments to Federal Courts of Appeal and District Courts, President Franklin Roosevelt, Truman, Eisenhower and Kennedy did not go below ninety percent. Woodrow Wilson's record was 98.7\%.20 At least one Canadian study has shown a similar tendency, if not as extreme, and the common knowledge of the legal profession will affirm that such a tendency exists. ${ }^{21}$ The appearance so created is precisely the appearance which will alienate public opinion and diminish public confidence.

\footnotetext{
16 J. T. Weir, President, circular letter to Canadian Bar Association, 1966.

17 Hon. Tom C. Clark, supra, n. 15 at 7.

18 Id. at 8.

19 Grossman, Lawyers and Judges 33 (1965).

20 Id. at 33.

21 One survey indicated that all but a few of the judges appointed during the survey period were affiliated with the party in power at the time they were appointed and most were actively engaged in politics: (1967) 1 Canadian Legal Studies 217.
} 
This is not the first time that proposals for change have come to the Canadian Bar Association. In 1918, the report of the Committee on Administration of Justice was carried by the annual meeting. This report urged "that these appointments should be independent of patronage control and that recommendations from the Bar Association and Law Societies as to the fitness of those available for such positions should be solicited and should have weight."'22 In his presidential address in 1929, the Honourable Wallace Nesbitt, a sometime judge of the Supreme Court of Canada, suggested that appointments be made by the Minister of Justice from lists provided by committees of lawyers named by the governing bodies in the provinces. ${ }^{23} \mathrm{~A}$ forthright declaration in favour of appointments of judges with regard only to their qualifications for their positions was made by $R$. B. Bennett in the presidential address of $1930 .{ }^{24}$ General J. A. Clark as president of the Association carried on a vigorous campaign against partisan appointments. ${ }^{25}$

In 1966 the Association established the National Committee on the Judiciary which has been in operation since March, 1967. The constitution and procedures of this Committee are described by Mr. Gordon Stirling.

I believe that the National Committee on the Judiciary is not a sufficient answer to the problems of judicial selection. I believe that it is subject to a number of defects.

An unseen operation of one vested interest (the legal profession) is not of itself a sufficient guarantee that the values and needs of the general public will be sufficiently recognized. It is not at all certain that a group of senior members of the profession accurately reflects the values of the profession itself. The Committee does not choose the names to be considered and therefore does not give any assurance that they are the best names or that they have been chosen by the best means. The Committee is not asked whether the prospective nominee is the best one available, or even where he ranks, but only whether he is qualified:26

My policy is to go to this particular committee of the Canadian Bar Association and say: 'I am thinking of appointing so-and-so; I should like to know whether in your opinion he is qualified.'

Further:27

The members of this Committee have been extremely helpful to me in making sure that any person I have named at least did not have a black mark against him with the bar.

There is no assurance that the Minister accepts the advice: ${ }^{28}$

Again, to the best of my memory, I have made no appointment of a person which had met with the disapproval of this committee. That does not mean $I$ am bound to continue in this direction.

I suggest that an appropriate adaptation of the Missouri Plan be adopted. This plan has long been advocated by the American Judicature Society and has been approved by the American Bar Association and has

\footnotetext{
22 Angus, supra, n. 13

23 Id. at 239.

24 Id. at 240 .

25 Id. at 243.

26 Hon. P. E. Trudeau, Minister of Justice, 112 House of Commons Debates 4896 (November 30, 1967).

27 Id.

28 Id.
} 
significantly contributed to judicial reform in the United States. Their constitutions and their problems are, of course, different from ours and their plan is not in detail appropriate for us in Canada. I believe, however, that the basic problems of ensuring the best selection and maintaining public confidence are much the same, and the basic proposal of a nominating commission independent of the appointment authority is equally appropriate to Canada.

The President's Commission on Law Enforcement and the Administration of Justice had this to say: ${ }^{29}$

The Commission believes that far more important than the choice between elective and appointive systems, however, is the existence in the selection system of an effective procedure for the screening of potential candidates for the judiciary on the basis of their personal and professional qualifications for office. The group that performs this screening function should be established by law, should be directly responsible to the appointing authority, and should be carefully selected to insure that its membership is representative and is not drawn from an unduly narrow segment of the bar or the community.

The Commission believes that the best selection system for judges is a merit selection plan generally of the type used successfully in Missouri for some twenty-five years, and long supported in principle by the American Bar Association and the American Judicature Society. The Missouri type plan is now in use with a number of variations in some ten states. Its basic approach is also embodied in the procedures used by the mayor of the city of New York to appoint criminal court judges. The Missouri plan is characterized by four elements [two of which are:]

1. The nomination of a panel of judicial candidates by a nonpartisan commission composed of conscientious, qualified laymen and lawyers.

2. The requirement that the executive appoint judges only from the panel submitted by the commission. ...

I propose that in each Province a nominating commission be established to suggest names to be considered for appointment by the appointing authority to the superior, district and county courts. The precise composition of such a Commission may well be open to argument, and the proposal should not stand or fall upon an exact list. By way of example, however, such a commission could consist of:

(1) The Chief Justice of the Province or his nominee, as Chairman.

(2) Two members appointed by the Federal Minister of Justice.

(3) Two members appointed by the Provincial Attorney General or Minister of Justice.

(4) One lawyer representative of the legal profession. He could be elected by the members of the profession, or an arrangement could be worked out for the appointment to be made by the governing body or the Canadian Bar Association or both.

Except for the judicial member, the members should be appointed for fairly short, rotating terms. At least two members should not be lawyers. The Commission should have administrative help and should operate continuously. It should supply a list of three to five names for each appointment. The appointing power should not be bound to accept the Commission's suggestion but should do so as a matter of practice and should state whether or not this has been done.

It is said that such a Commission would itself be affected by politics and by lobbying. No doubt it could be. However, the diversity of personnel and of the sources of their appointments would make lobbying

\footnotetext{
20 The Challenge of Crime in a Free Society: A Report by the President's Commission on Law Enforcement and the Administration of Justice, United States Government Printing Office, February, 1967, at 146.
} 
difficult. The same factor would tend to ensure in fact, and assure in appearance, that the only thing under consideration would be merit. A Commission so constituted, unlike the executive arm of Government, would not have any common interest other than an interest in performing its function properly. The system would be obviously designed to find the best judges and would strengthen public confidence. The executive would not be shackled, but it would be encouraged to make choices based only on criteria relating to fitness. Lawyers who engage in politics would not be excluded; in fact, political activity in all parties and at all levels of government would be a recommendation for appointment.

I submit that the establishment of independent nominating commissions to submit names to the appointing authority would be a major and significant reform in the interest of the public, the Bench and the Bar.

\section{Discipline and Removal of Judges}

An independent judiciary must remain one of the great objects of public policy. The executive must not be in a position to punish or reward a judge. An honest and capable bench is another great object of public policy. There should be some mechanism to ensure that judges do their duty and, if necessary, to remove those who will not or cannot do so.

Parliament has made an attempt to reconcile these objectives and to achieve both of them by an admendment to The Judges Act which has been enacted as 1970-71-72 Statutes of Canada, Chapter 55. This Act provides a mechanism for the removal of judges. The mechanism requires a recommendation for removal from the bench itself.

Under the Judges Act as it was before the amendment, the Governor in Council could institute an inquiry into the conduct of a superior, district or county judge. The inquiry was to be made by a judge of a superior court or of the Supreme Court of Canada or of the Federal Court. Upon receipt of the report of the inquiry, the Governor in Council upon the report of the Minister of Justice was empowered to stop the salary of a judge who was found to have become incapacitated or disabled from the due execution of his office by reason of age or infirmity. ${ }^{30}$ The Governor General in Council, following receipt of the report, could also remove a district or county court judge for misbehavior, or incapacity or inability to perform his duties properly by reason of age or infirmity. The Act did not say that the Governor in Council could not proceed even if the inquiry resulted in a favourable report, but it would be almost inconceivable that a favourable report would not be accepted.

There was a distinction between the position of a district or county court judge on the one hand and a superior court judge on the other. The latter could be removed only upon an address to both Houses. ${ }^{31}$

The Judges Act now provides for the "Canadian Judicial Council." The Council is composed of the Chief Justice of Canada and the Chief Justice and Associate Chief Justice of each superior court or their alternates. They are required to meet at least once in each year. The Council is required, at the request of the Minister of Justice of Canada or the Attorney General of a Province, to commence an inquiry as to whether a judge of a superior, district or county court should be removed

30 The Judges Act, R.S.C. 1970, c. J-1, ss. 30 to 32 .

31 British North America Act, 1960, 9 Eliz. II, c. 2 (U.K.). 
from office by reason of age or infirmity, misconduct, having failed in the due execution of his office, or having been placed "by his conduct or otherwise" in a position incompatible with the due execution of his office. The Council may investigate any complaint or allegation made in respect of a judge of a superior, district or county court. ${ }^{32}$

The Council may designate one or more of its members "who, together with such members, if any, of the bar of a province, having at least ten years' standing, as may be designated by the Minister of Justice of Canada" are to constitute an inquiry committee. The inquiry committee has various powers and must conform to a due process provision. ${ }^{33}$ The Council is then to report its conclusions and submit the record of the inquiry or investigation to the Minister of Justice of Canada. There is a hiatus as to what happens between the inquiry and the formulation of the conclusions of the Council. The Council may recommend that a judge be removed from office and that his salary be stopped..$^{34}$

The Minister of Justice of Canada is then to report to the Governor in Council. If the Governor in Council finds that the judge has become incapacitated or disabled from the due execution of his office his salary is stopped, and, in the case of a district or county court judge, the Governor in Council may remove him from office. Presumably, in the case of a superior court judge an address would be moved in both Houses. Provision is made for the Governor in Council to grant leave of absence to the judge, and provision is also made for pension if the judge resigns. ${ }^{35}$

The introduction of the Judicial Council into the removal procedure seems to be a valuable protection to the independence of the judiciary, while affording some mechanism which can operate more efficiently than the present mechanism.

However, if the Council is to operate effectively, it must have an office and some administrative staff. If a body is to receive complaints it must have a place to receive them and a method of dealing with them. It may be expected that there will be a reasonably substantial number of complaints, though the great bulk of these may confidently be expected to be from litigants unhappy with the disposition of their cases. It is to be hoped that the Council will develop informal methods of pointing out errors into which judges have fallen but which do not justify the application of any of these sanctions.

I think that some further procedural provisions should be added to cover the hiatus between the inquiry or investigation on the one hand, and formulation of the Council's conclusions on the other. Does the Committee report to the Council? If so, is the Judge entitled to appear before the Council? Is he entitled to be heard by the Minister? Is he entitled to be heard by the Governor in Council? If he is a superior court judge, is he entitled to be heard by a Committee of the House, of the Senate, or of both? In the absence of specific direction, or of the granting of discretions, it seems likely that there could be difficulty in working out the procedure to be followed in a given case.

There is one peculiarity in the grounds for the stopping of salary and for dismissal. A Judge who is "placed, by his conduct or otherwise, in a

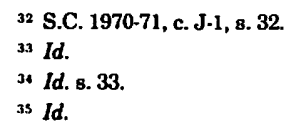


position incompatible with the due execution of his office" is subject to these sanctions. It is not easy to see just what effect the words "or otherwise" will have, but they seem to contemplate grounds having something to do with things other than the conduct of the Judge himself, which seems undesirable.

These are matters of detail. The principle is a good one and, if given proper effect, will provide new and important safeguards for the public interest.

\section{REMARKS BY F. C. MULDOON, Q.C.}

I think, in addressing myself to the topic of this panel discussion, that if no other panelist has been assigned or voluntarily undertaken the role of bête noire, it ought to be mine.

First then to be negative for a few minutes. There are a couple of relatively inarticulate, rather major premises which I think I perceive on the part of our profession, with which I fundamentally disagree. One of these premises is that when it comes to advising on matters of the judiciary, this voluntary association of the Canadian Bar, and the governing bodies of the provinces have some of the consecrated attributes of a kind of royal priesthood. I would not wish to belittle the voluntary good works of the bar, especially in advancing the work of law reform; but I sense still much of a kind of elitist euphoria which takes a heavy toll of our credibility when we purport to advise on the selection and appointment of judges. It was long ago that Mr. Justice Trueman of the Manitoba Court of Appeal said: ${ }^{36}$

... Lawyers in Canada are born in the purple and bred in the great traditions of the English Bar and Bench. Nothing of a lesser mould will content us.

One would think that such an attitude would long since have evaporated. I must state candidly that I have little, if any, objective, specific evidence to offer you on this occasion to support my assertion of the survival of a somewhat humourless patrician attitude on the part of the organized bar of this country, but I do perceive, in commom with many other lawyers, that our profession does manage to communicate such an impression to the general public. Before the Bar can make any influential and persuasive proposals about the selection and appointment of judges, without attracting the deepest suspicion of motives, it must first rid itself of the pomposity of elitism.

The other disagreeable major premise which becomes all too articulate when we speak or write of the judicial appointments in this land is that there is something sinister or scandalous about political partisanship. Perhaps the inefficiency (as that word is understood in a commercial or industrial sense)-the inherent inefficiency of democracy bothers us. However, unless we were to subvert it, the great hallmark of democratic government is the right of the people to select, from among contending partisan political adversaries, who shall govern. I assume that I am in the company of many fellow-lawyers who, from time to time, bear the worry or even the fear about how much popular affection and support our civilized and still useful democratic institutions ultimately would enjoy in time of dire crisis. I think most of us have recently pondered that from time to time. Without politicians engaged in parti- 
san competition, we should have no democratic institutions-or else they would be blighted bland ones of extremely short half-life. And yet, when it comes to the sensitive subject of judicial appointments, we of the Bar seem to join in the all too general distaste for, and even mockery of, politicians and political processes, including political appointments. This, it seems to me is very counter-productive in practice, in theory, and in ethic.

One of the arguments presented against the political input to the selection of judicial personnages is a strained analogy to government seeking and retaining the services of eminent scientists. In obtaining the best scientific talent, government casts about for the opinions of other scientists, and politicians recognize that they themselves are not particularly qualified to assess scientific merit. One does not devalue the imagination, innovativeness and intellect necessary in scientific pursuits, when one observes that judicial performance is perforce different. A judge leads, in his proper sphere, a very public life indeed, and exercises his judicial functions and powers in, and on behalf of the body politic. In this sense the judge is, and must be, a kind of politician even though he does not campaign to remain in office and he must always and everywhere be scrupulously non-partisan. I think that we, as a profession, have manifested disdain toward the political selection and appointment of judges, not because the appointments have been universally bad-they haven't been that way at all. Most are, I think, quite felicitous-but it is because we as an organization constitute a kind of establishment without as much influence as it desires. As a well known lawyer-politician recently said whimsically, but indicating a deep appreciation of human behaviour: "Lack of power corrupts, and absolute lack of power corrupts absolutely." The majority of appointments are then, perhaps surprisingly, apt because, in Canadian society, there is probably no more broadly based institution than a political party in power. It is surely a much more broadly representative institution than the Canadian Bar Association can ever hope to be. In my view, political input to the process is proper and ought not to be eliminated, even if it could be eliminated.

One must, however, concede at least two defects of a wholly political process of selection and appointment of judges, especially if it be conducted on an exclusively partisan basis.

The first defect is: that to the public at large the process, being conducted in the private inner sancta of the Minister of Justice, his colleagues and their political party, generates the very worst suspicions of the methods by which the successful appointee might attract the favourable attention of the party in power. Probably not all of those suspicions, when they arise, are well founded, and they do not arise with each and every appointment. However, the suspicion that judicial appointment could be won by blindly, ruthlessly loyal partisanship no doubt makes some people speculate that the very effort to get appointed must so warp the temperament and instincts of the aspirant as to render him unfit for that to which he aspires. Equally, the suspicion that appointment to the bench could be won in and by virtue of the "clubby" atmosphere of social or'business contacts with federal ministers and M.P.'shere is that patrician, elitist aspect again-must disturb large sectors of the public. This is not to say that there haven't been and aren't still many judicial appointments which are warmly applauded by the public at large and the profession in particular as meritorious. Still others turn out 
better than first anticipated. We are probably all aware of recent events in Manitoba where a Minister of the Crown (who quite sincerely, and most probably quite rightly, asserts that he himself is most representative of the ordinary person) publicly voiced just those actual suspicions-and more. If such suspicions be widely held, it matters not if they be generally false: their existence alone is corrosive to the administration of justice, and by some effective means they ought to be put to rest. It is no answer to label those who harbour such suspicions as ignorant or wrong-headed and pass on to other matters.

The other obvious defect of our political process of selection is that it can be, and is, exclusionary. While it may and does produce judges of ability and merit, nevertheless it generally excludes other able and meritorious people from consideration for appointment because of partisan loyalties, or because they exhibit a very low or even non-political profile in the community.

I cannot but maintain my own assertions uttered at our 1966 C.B.A. meeting in Winnipeg that the interjection of the Canadian Bar Association into the process would not be-and has not been-any real improvement. Because we cannot be privy to the workings of the National Committee on the Judiciary; and we cannot be with them individually as they gather their long-distance hearsay about prospective appointees; and we cannot weigh the awesome subtleties and permutations of consensus as between the "well qualified" and the merely "qualified" postulant; nor yet know the precise mechanisms of the distinction-we simply cannot, either as an Association, or as members of the public, assess the Committee's workings. We can have faith, of course. For myself, I repose as much faith in elected politicians-in-office as I do in the distinguished members of the Committee on the Judiciary. And why not? Both groups are composed of sincere, responsible persons who are operating in this particular area of extreme confidentiality as best they can, given the present system. To say that the one group is political because they are elected partisans, and the other group isn't political because it is of the Canadian Bar Association, would be to say something naive.

So, it appears that if the presently-constituted process of selection and appointment lacks public confidence, the obvious reform would involve the elimination of the suspect partisan, and evidently exclusionary, features of the selection and appointment of judges. The process, if it were to be changed, ought to be changed for the better, so that its credibility will be enhanced in the public interest. To achieve the desired credibility the quest for quality judicial material therefore ought to become even more broadly representative of the community in which the judge is to function than can be attained through the network of a national political party in power. Although this proposition may appear paradoxical, it cannot be shrugged off, because the unilateral or elite group approach cannot seriously be propounded as a reform. Some form or aspect of a kind of collegiality has been advocated or tried in various jurisdictions on this continent for over half a century although the actual attempts are more recent. An interesting and, I think, acceptable form of collegial action (in reality arbitration) was proposed as recently as this year in the late, lamented Victoria constitutional charter.

If one accepts some form of collegial or representative selection-and 
one can hardly decline; if those partisan, exclusionary features are to be eliminated-then the composition of the nominating collegium or commission is of paramount importance. I perceive wisdom and merit in the type of Nominating Commission proposed by Mr. Hurlburt, but I am not wholly content with its composition. For example, the inclusion of the Chief Justice of the province, or his nominee (presumably a judicial brother) as chairman could tend to influence the Commission toward the nomination of "teacher's pet" types rather than the ideal type of person who is his own man and well able to endure the necessary loneliness of judicial office. I say nothing against the ethical integrity of provincial Chief Justices by my raising of this doubt, and it does not spring from paranoid vapours of imagination. I did, however, note that Richard A. Watson, in a paper entitled "Judging the Judges" described the operation of such nominating commissions in Missouri, and he asserted:37

\footnotetext{
The influence of the sitting judges of the (state's) Supreme Court, channelled through its chief justice (who serves as ex officio chairman of the appellate nominating com. mission) was evidenced by the number of nominees and appointees of the Supreme Court who previously served as court commissioners. (Commissioners, who are appointed by the court itself, participate in hearing cases and writing opinions, but do not vote on the final disposition of cases.)
}

Perhaps my doubts are ill founded, but I think it would be inappropriate to place a provincial Chief Justice (who would be an enormously influential member of the nominating commission) in the position in which he might be suspected of having and promoting favourites. Indeed, it is not unheard of that judicial appointments are made from within the judiciary itself. Let some other independent person of designated independent and disinterested office, such as a provincial Ombudsman, a Law Faculty Dean or even a Law Reform Commission Chairman preside over the nominating commission. Nothing, of course, would preclude the Chief Justice from being a useful resource in the researches performed by the nominating commisssion.

Of the two appointees of the Minister of Justice on this nominating commission, one should be a lawyer and the other a layman; and likewise with the two appointees of the provincial minister. It would be most salutary (but perhaps unlikely), I think, when there exists a partisan identification as between the party in power in Ottawa and in the province (as for example there exists today with the provinces of Quebec, Nova Scotia, Prince Edward Island and Newfoundland) that the practice develop that one of the provincial minister's appointees be the province's Leader of the Opposition or his "shadow" Attorney-General, or the opposition leader's nominee. Since this proposal envisages (properly, I think) that the sixth member of this nominating commission be a lawyer appointed by the governing body of the legal profession, or elected by the members, I should prefer that the other two lawyers be neither Benchers nor the partners of Benchers. I would, you see, aim for broad representation without raising the suspicion of vested interest, but also without necessarily sacrificing competence. If one were to make the change expressed in this proposal one might as well make it thorough, effective and not'so as to engender criticisms similar to those levied against the present process. In this regard, it would be better that the body be as its proposed designation suggests-a nominating commission

${ }^{37}$ (1970) 53 Judicature 283 at 288. 
-rather than a mere screening body. It is better to be an author than a mere proof-reader. However, if the federal authorities will not accept an author, then it is better at least to be a proof-reader then never to have been born at all!

This idea for nomination of selected, quality judicial material is, as might be expected, not perfect. Although it probably would overcome the principal criticisms of the present process, it would after all, erect an expensive new investigative and deliberative bureaucracy in place of the simple, relatively direct and inexpensive process by which judges are now selected and appointed. And would it be beset by the self-promoters! How much easier and more efficient it would be to toady to the local nominating commissioners than to make the requisite pilgrimages to Ottawa to meet the Minister by which, I understand, some aspirants hope to enhance their chances of judicial appointment. Let no one regard this proposal lightly; it would take an exceptionally high, sensitive and historic degree of altruism (some will call it lunacy) for any federal government of whatever political stripe, to share or dilute the power of selection and appointment of judges which the constitution reposes in it. Indeed, the only valid premise upon which it should do so, is to serve the continuing public interest. If the principle of judicial nominating commissions were ever satisfactorily effected, it could be extended mutatis mutandis to the Federal Court of Canada and the Supreme Court of Canada on the one hand, and to provincial courts presided over by provincial appointees, on the other.

If such nominating commissions were properly staffed and able to provide a list of several names for each appointment, their role in the selection and appointment of judges would go far to enhance public confidence in the judiciary in those very aspects by which the present system engenders public doubt.

The question of discipline and removal of judges presents some problems for which, I confess, I have no solutions; only observations. Under the provisions of Bill C-243 there would be created the Canadian Judicial Council composed of the Chief Justice of Canada together with the Chief Justice of each superior court (or their alternates). The Council may investigate complaints about any "Section 96" judge. The Council then reports its conclusions, with the record of its proceedings, to the Minister of Justice. It is empowered, as well, to recommend removal from office and stoppage of salary. The Minister then reports to the Governor-General-in-Council, and it may be that the ultimate decision is removal from office-let us say from a superior court. But what if, after all the documentation and recommendations, one or other House of Parliament (or each) declines to pass the constitutionally required address? The harm would be enormous. Either the judge would appear to be a culprit, so found, but unpunished, or the Judicial Council could be publicly regarded as malicious nitwits. In my opinion, because of the power, independence and therefore prestige which judicial appointment confers, one must treat a judge either with deference or despatch. It is quite contrary to the public interest that the repository of that power, independence and prestige should be officially rebuked or disciplined and remain a judge. However, it may be that the Judicial Council would be more effective in potential than in practice. Otherwise, a re-casting of the Judicial Council's powers would be necessary, together with a re- 
casting and general amendment of Section 99 of The British North America Act. It is the latter provision which accords superior court judges security of office "during good behaviour" and renders them removable only "by the Governor-General on address of the Senate and House of Commons."

\section{REMARKS BY THE HONOURABLE E. D. FULTON, P.C., Q.C.}

My remarks will be confined to the method and problems of appointment of judges by the federal authority only, since this is the field with which I am familiar; and, whatever may be agreed as the method or principles governing selection and appointment by one level of government will be capable, at least in principle, of application to and exercise by, the other. Within that context, I should like to deal with three aspects of the problem:

1. The problems inherent in the proposals for a system of nomination by other than the responsible political authority.

2. The role and responsibility of the profession.

3. Current proposals as to the method of selection and appointment to the Supreme Court of Canada.

\section{Responsibility for Selection and Appointment} The issue here seems to be the following:

(a) Should the initial responsibility for selecting appointees to the Bench be transferred to a formally appointed non-governmental body who will select and submit a panel or panels or names of persons considered qualified, from amongst whom the Minister should appoint one?

(b) Or should the initial responsibility continue to rest with the Minister, to canvass the field of qualified persons, and to discuss the names of the proposed appointee with a non-governmental body for advice as to whether or not he is in fact well-qualified?

I have considerable sympathy with the aims of those who advocate the first mentioned system, because their motive is to ensure the appointment only of well-qualified persons. With this objective, I am sure we are all in unanimous agreement. But I do not agree that this is the only method of achieving the result-nor do I agree that it is the best method, because I consider it has dangers or weaknesses that may be greater than those it seeks to avoid. There is no doubt that professional qualification should be the prime governing criterion for appointment to the Bench. One cannot exclude, however, other considerations and criteria-the possession of a judicial temperament, understanding, broad experience, social consciousness, and qualities of bearing and conduct towards others. There is equally no doubt that political qualification in the partisan sense must not be allowed to override the consideration of professional and other qualifications mentioned. This has been the theme and the intent of innumerable resolutions and representations of the Canadian Bar Association on this subject. It was with this object in mind that I assured the Executive of the Canadian Bar Association in 1957 that as Minister of Justice I would make it a practise to consult with the appropriate judicial and/or legal bodies before making or recommending appointments to the Bench.

It is true that no formal rules were set up at that time, but the prac- 
tice was followed. I am happy to see that a degree of formalization of the process has been introduced-although there are dangers in overformalization, as pointed out by Mr. Stirling, and to some of which I shall refer later. But I was then and am now in entire agreement that there should be the assurance of consultation before appointments are made, in order to ensure the objectives mentioned-the paramountcy of the criteria of proper professional and personal qualifications. But I believed then-and I believe now-that the prime responsibility and initiative must remain with the appointing authority. It does not seem to me that this will be the case if there are set up a body or bodies not having any authority to make the actual appointment, and not having any real responsibility if an appointment turns out badly, but having an express-or even an implied-right to submit lists from which appointments must be made.

One of the background papers to which we have been referred speaks of the "faceless mask of the Cabinet confronting the public in judicial selection". ${ }^{38}$ This is in the context of the desirability of a more direct responsibility or accountability for the quality of judicial appointments-particularly if they are bad. How much more faceless the mask would be, and how much less accountable the Minister or the Cabinet would be, if there were interposed a mechanism by means of which he or she could say: "But we had no responsibility in the matter-we simply acted on recommendations that were made to us, and which we were bound to accept." Those who advocate the system of nominations by an outside independent, non-political body, from which nominations the appointments must be made, say, "the only way to avoid the imposition of political considerations is to have such a non-political organization submit lists of eligible appointees."

In reply, we may ask: "Is it really to be supposed that politics is confined to governments and to political parties?" There is politics in every organization that has elected officers and an elected executive. So is there an 'establishment' in every organization. The establishment can be changed-and is changed every so often-by the votes of the members of the organization. That is the process of politics. In this sense there is politics in the Bar Association, there is politics in the Law Society; there is also an establishment in each of them. There has to be, because again by its very nature there is politics in every organization that has an elected executive.

But in our system of democracy there is only one organization that is responsible to all the people-that is the Government, through Parliament. And it is the country generally, not just the lawyers, that suffers if bad appointments are made. Of what benefit then is it to substitute the politics of a non-responsible body - that is, not responsible to the general electorate-for that of a body that is so responsible? What penalties will attach to the Canadian Bar Association or the Law Societyor any other "non-political" organization or body-if an appointment they have initiated turns out to be wrong?

So I suggest that unless and until we decide to change the system of responsible Parliamentary democracy, under which the Government

38 Angus, Constitutional Reform: The Judiciary, presented to the Annual Meeting of the Association of Canadian Law Teachers held at the University of Calgary, June $6,1968$. 
is responsible through Parliament to the people for all its actions, the responsibility for judicial appointments should be left where it now lies.

Indeed, there are other factors, not paramount but important, which must be taken into consideration as well as the paramount consideration of professional qualification. Not political factors, but factors that are the inescapable responsibility of Government, and for which it and it alone must accept responsibility. Consideration may well be given to a more formal and comprehensive system of consultation. But care must be taken that the system is not so formalized as to court the danger of turning our professional associations into an internal lobby. Consultation is essential to ensure the necessary high standard of qualification for appointment; but however extensive or formal the system of consultation may be, I do earnestly suggest that that is exactly what it should remain; consultation, not nomination.

\section{Professional Responsibility}

Turning to my second theme, the responsibility of the profession, I would like to think that every lawyer would regard an appointment to the Bench as the crowning point of his career. We all, as citizens as well as lawyers, have an interest in and responsibility to ensure the quality of the judiciary. I have already repeated that there should be full and effective consultation to ensure that appointments maintain that quality. But it is surely not going to be possible to achieve that goal of a worthy and qualified judiciary unless qualified lawyers are willing to accept an appointment when it is offered. It is dangerous, of course, to make absolute and categorical statements, but it is surely a principle that should guide the profession, that the privilege of our calling carries with it certain duties and one of those duties is the duty of accepting an appointment to the Bench when it is offered.

This of course imposes a duty of common sense and understanding on the part of those making or offering the appointment. There are circumstances where it would be impossible for an individual to accept and these circumstances should be carefully considered before any formal approach is made. Financial considerations do enter in-a person has a paramount responsibility to his or her family. The level of judicial salaries has been improved; however, it continues to be the responsibility of the profession and the Government to keep salaries under review to ensure that qualified lawyers are not in a practical sense debarred from accepting. Notwithstanding the best efforts in this regard, it is true that there will often, if not always, be some element of sacrifice-if not financial, then physical, such as moving one's home and family to another location. Nevertheless, it is surely the only acceptable principle, to which rare exceptions are permitted, that a call to the Bench, if it comes, is a duty which must be accepted. This has not always been the case in Canada.

\section{Appointments to the Supreme Court of Canada}

The third matter which I want to put before you is the proposal, placed before the last session of the Federal-Provincial Conference on the Constitution of the Prime Minister and provincial Premiers, as to a new method of appointing judges of the Supreme Court of Canada. While no legislation has yet been introduced or even forecast, it appears that this proposal was accepted in principle at that Conference, 
and it is a matter to which I believe this Association should give very serious and urgent consideration. If I understand the proposal correctly, it can be summarized by saying that first, there would be a formal requirement that every future appointment to the Supreme Court of Canada would require the approval of the Government of the province from the Bar of which the appointment is made; second, that this approval would have to be formally sought and formally given; and third, that in the event of disagreement there would be a formal but fantastic process of arbitration (which has been described as a pingpong process) by which the disagreement may be resolved.

Now this is not an application of the principle of consultation, which was discussed earlier. In my view, it is not even a mere extension of it. It is a radical change in the power of, and responsibility for, appointment; for under this system no appointment could be made without, in effect, the formal approval and sanction of the Government of the Province, obtained either directly in the first instance or indirectly through the arbitration process. I will not do more than mention one or two of the obvious questionable features of this suggestion. One is the matter of the dignity of the Bench: What is to be the lot and position of a Judge appointed after formal objection to his qualifications or suitability has been made by one of the parties to his appointment, resolved only by a process of arbitration? And it should be noted that this goes further than the United States system, where the President appoints and the Senate may or may not ratify; here the Province would become an appointing power. Another is the question of further erosion of the Federal power; but that may perhaps be more properly debated in a purely constitutional forum, rather than in one concerned with the quality and integrity of the judiciary.

The main point which I wish to raise here is one which concerns the basic principle of the judicial process; that Judges are judges of the issue, not partisans of the parties to the issue. It seems inescapable that the imposition of such a system as outlined would, by necessary implication if not by direct enactment, involve acceptance of the principle that judges of the highest court in Canada are chosen not because they are expected to be good judges of the law, but because they are acceptable as partisans or representatives of a position or interest.

Admittedly, it is necessary to ensure fair representation of all regions of Canada on the Supreme Court. There are omissions now; if desired, this can be rectified by a simple amendment increasing the number of judges-perhaps the workload alone would justify this. Admittedly also, it is essential to ensure a proper proportion of Judges to deal with issues involving the Civil Law arising in the Province of Quebec. There is provision now for a minimum number of Judges of the Supreme Court of Canada from that Province; if it is felt to be insufficient, this can be rectified by a simple amendment increasing the number of Judges in the Supreme Court of Canada who are required to be-or have beenmembers of the Bar of that province trained in the Civil Law. Admittedly also, the Supreme Court of Canada will be increasingly concerned with constitutional issues, but if it is felt that the Court does not now contain a sufficient number of Judges trained and experienced in constitutional law, that weakness, if there be one, can be rectified by the process of ensuring the appointment of those trained in constitutional law.

By a combination of all or some of these methods, if there are felt to 
be present weaknesses in these regards, due assurance could be given of a sufficiency of Judges familiar with the regional, legal, and cultural problems peculiar to the areas from which they come, which are indeed a part of the very fabric of the kind of issues which arise in our country. But surely the basic principle is important, and worth maintaining, that they approach these issues, whether arising by way of private litigation or constitutional dispute, as Judges of the law and Constitution, not as spokesman for, or representatives of, a particular region or interest.

If we are concerned that the paramount consideration in respect to judicial appointment be professional qualification, surely this applies with special emphasis to appointments to the Supreme Court of Canada. Why then is it suggested that the consent and authority of a Provincial Government to such an appointment is necessary, unless it be to accept the necessity-or even the possibility-of some other consideration or qualification. Whether it be necessity or possibility, either is surely equally objectionable.

Wherever you have persons of differing views and different interests, there may be doubt or disagreement in individual cases as to whether the best appointment has been made-just as there will inevitably be disagreement as to whether the right decision has been made in any case. But whatever the disagreements or differences of opinion as to the method of appointment, it is surely the concern of the lawyers of Canada that the integrity of the judicial process be maintained and that those selected be selected because it is felt that they are best qualified to be Judges of the law as applied to the issues before them, and not for any other reason.

I invite the consideration of this Sub-Section, and of the Canadian Bar, to the question of whether the system suggested for the appointment of Judges to the Supreme Court of Canada does not, however unintentionally, involve a departure from that principle.

\section{REMARKS BY THE HONOURABLE SIR ROBERT MEGARRY}

I speak to you as one of that band of men known as judges, who, as you have heard, are uneducated before appointment to office and continue unrefreshed after appointment. As you all know from personal experience that a judge is someone who remains totally silent until the conclusion of the proceedings, you will hardly expect me to speak; yet I must say something.

First, I must make a brief disclaimer. Naturally I shall say nothing that comes from any confidential source; I merely recount what is generally known or believed by the English Bar, or is in the public domain. That said, I may begin with the formal details of appointment to the Bench in England. It is briefly told. There are three main categories of judges, and I give the figures in round numbers. First, there is the High Court and above (Court of Appeal and House of Lords), with a total of 100 . Second, there are 125 county court judges; and third, there are 50 stipendiary magistrates. That makes a total of 275 . All are appointed by the Crown on the advice of the Lord Chancellor or, in the case of the Court of Appeal and House of Lords, the Prime Minister. The responsibility for this advice is individual and not collective; it is not a Cabinet matter. The Prime Minister is generally believed to consult closely with the Lord 
Chancellor before making his recommendations, and so it is the Lord Chancellor who in substance is the great appointer to the Bench.

The Judicature Act, 1925, s.12, replacing provisions in the Judicature Act, 1873, and the Act of Settlement, 1700, provides that judges of the Supreme Court (that is, the High Court and Court of Appeal) hold office "during good behaviour", subject to a power of removal by the Crown "on an address presented to His Majesty by both Houses of Parliament". No English judge has ever been removed under these provisions, but in 1830 Sir Jonah Barrington, a judge of the Court of Admiralty in Ireland, was removed for misconduct and malversation in office. That is all. County court judges and stipendiary magistrates are in effect removable by the Lord Chancellor for inability or misbehaviour. I know of only one such removal. In 1851 Judge Ramshay had become very eccentric indeed, and after a hearing he was removed from office. From his chambers in the Temple he continued to send letters to court officials asserting that he was still the judge, and adjourning the court, but all to no avail; and quo warranto proceedings against his successor failed: Ex p.Ramshay (1852) 18 Q.B.173. So we have little experience in this field that would assist you. At the same time, it is said that there have been some instances-a very few-in which the Lord Chancellor and others have encouraged a resignation; but that is a little different. Other and more subtle forces, and not least, association with the Bar, and the influence of the Inns of Court, do much to sustain the judge in England in the difficulties of his office.

Retirement? This is now mandatory at 75 for High Court judges and above, at 72 for county court judges, and at 70 for stipendiary magistrates. Machinery for discipline? Nil. Training? Nil. And so on that footing I seem to be of very little use to you. Yet I think that we have been merely looking at the tip of the iceberg. We must look a little below the surface if we want to get a balanced picture. Let me mention, as briefly as may be, seven factors which help to show the realities.

1. There are relatively few appointments to be made. With a population for England and Wales approaching 50 million, there are a little less than 100 judges of High Court level and above to do all the trial and appellate work; and that comes to two judges per million of population. At the same level, Canada has roughly five and a half times as many judges per million population, and about three times as many at the county court level; if one ignores the size of the population and takes absolute figures, yours are of the order of 250 and 160 as compared with our 100 and 125. There are, of course, many reasons for this, not least that of the respective sizes of our countries; even if one excludes the Yukon and the Northwest Territories, the area of Canada is some 35 times greater than that of England and Wales. But the point is that with fewer appointments to make, both absolutely and relatively to the sizes of population, the agony of appointment arises considerably less frequently with us than with you.

2. The field from which appointments are made is much smaller in England than in Canada. Three main factors play their part: specialization of function, specialization of subject-matter, and age. The first head primarily refers to the division of our legal profession into barristers and solicitors. Of a total legal profession of some 28,000 or 29,000 , less than one-tenth, about 2,600 , are practising barristers. With certain ex- 
ceptions at the lower levels, all appointments are made from the Bar, the branch of the profession that lives out its professional life in the courts. There is then the further division of barristers into Q.C.'s and juniors. Of the 2,600 practising barristers, rather less than 300 are Q.C.'s; and appointments to the High Court are nearly always made from among practising Q.C.'s. In fact, the field of choice is smaller than that, because after discounting those who are approaching retirement or have not been very successful, probably there are some 150 or 200 who do the great bulk of the work; and it is from them that the appointments will be made.

In England, of course, silk is a reality and not merely an honour. A junior who takes silk takes his professional life in his hands, for he has to give up all his smaller work, including settling pleadings, and, being unable to appear in court without a junior, must confine himself to the bigger cases; and the number of these is limited. A junior does not lightly apply for silk, and silk is not to be had for the asking. It is believed that something like four out of every five applications fail. Solicitors play an important part in this field. Nobody will be appointed a Q.C. unless many solicitors, on a basis of trial and error, have acquired a faith in his abilities as an advocate; and no Q.C. will get much work unless many more solicitors have faith in his forensic abilities at the higher level of silk. The collective judgment of solicitors thus plays. a large part in selecting the field of possible candidates for the Bench. Solicitors judge from knowledge and experience, too; unlike the lay client, they will not confuse a flashy but incompetent display with a restrained but skilled performance.

I need say little about specialization of subject-matter. Barristers tend to specialize in work which usually finds its way into one or other of the three Divisions of the High Court, Chancery, Queen's Bench, and Probate, Divorce and Admiralty (soon to become the Family Division); and within those broad divisions there are often specialist sub-divisions. This, of course, narrows the field. A Queen's Bench judge dies; who will be appointed in his place? You may be sure that it will not be a Q.C. who normally practises in the Chancery Division.

As for age, there is in practice a limited range for appointment. Looking at recent years, the average age for appointment to the High Court comes out at about 52 for the Probate, Divorce and Admiralty Division, 53 or 54 for the Queen's Bench Division, and 55 or 56 for the Chancery Division. The youngest age at which anyone has been appointed to the High Court this century is 42 and the oldest 65 (though I cannot forbear from mentioning that Sir Salathiel Lovell began his five years in the Court of Exchequer when he was 89; but that was in 1708). The normal effective range of ages is from the late forties to the late fifties. Again, this restricts the field of choice.

Let me take a melancholy but practical example. Suppose that, overwhelmed by the hospitality that I have been receiving here (and that is far from a remote possibility), I keel over and die before your eyes. A successor to my seat in the Chancery Division will then have to be appointed. Well, this does not look very difficult. In the Law List there is a list of the Q.C.'s who practise specially in the Chancery Division. There are 28 names there. Some of the more senior are over the age at which appointment is probable; others are too young or too inexperienced. There are other considerations, too, and in the end probably most lawyers who have any familiarity with the Chancery Division would agree upon 
the handful of names, perhaps two, three or even four, from which the appointment would almost certainly be made. The Chancery Division is small, with only ten judges, and the field is more open in the Queen's Bench Division, with some 45 judges. But even so, in most cases the question must come down to one of choosing from a very small number of possibles; and this must usually make the process of appointment far less complex than it must be in some other jurisdictions.

3. Most judges have had some trial runs on the Bench before being appointed. Your chairman touched on this a short while ago when he mentioned what Henry Cecil had said in his book. It is common for a potential judge to be appointed a Commissioner of Assize for a period of four, six or eight weeks at a time; and during this period he has the temporary status of a High Court judge. Again, many a barrister sits three or four times a year as a Recorder, or Chairman or Deputy Chairman of Quarter Sessions, spending perhaps some twenty days a year as a judge in criminal cases too serious for the magistrates and not serious enough for a High Court judge. Although the prime purpose of these activities is to get the work done, there is great value in the incidental result that it becomes known what sort of a judge the barrister is likely to make if he is appointed to the Bench. Nobody can really tell how anyone will behave as a judge until he has been seen performing as a judge. Being a judge is so different from being an advocate, not least in that the advocate knows which side he is on. There have been many instances of Commissioners of Assize demonstrating their suitability for judicial office, and in other instances demonstrating just the opposite, for a wide variety of reasons. Men react to the stresses of the Bench in remarkably different ways. Like the elephant, the judicial quality is easily recognizable but very difficult to define; and so this is one of the fields in which "Try it and see" becomes an important adage. By way of footnote, I may add that until 1933 Scotland even had a trial run for each newly appointed judge of the Court of Session after his appointment; but this had become a mere formality.

I would attach very little value to any formal training for judicial office. I do not see how you can effectually train a man to be a judge. You can, of course, teach a man the technique of driving a car; but it is the man and not his training that predominantly determines whether he uses wisely and tolerantly the skills that he has acquired, or whether he is a foolish and aggressive driver. The judicial quality is something that a man has or has not got; and whatever training may do to improve the native quality, it cannot graft a judicial temperament on to barren stock.

4. The Lord Chancellor, the great appointer of judges, is an active judge himself. He is a Cabinet Minister, of course, but he is far from being that alone. He is necessarily someone of a sufficient judicial stature to enable him to preside over the House of Lords, and command the respect of the other law lords. He does not merely sit in an office and in Parliament, but lives and moves in the world of law. He has long known many of the senior members of the Bar, and of course in the House of Lords he listens to many arguments. There is therefore much that he can decide upon his own first-hand knowledge, and not merely upon report.

5. Judges live and work with the Bar. If you are near the Inns of Court in London at lunch-time on any day during term, you will see that at about 1 p.m. most of the judges of the High Court and Court of Appeal and many of the practising members of the Bar are on their way to the 
halls of their Inns of Court for lunch. Each judge will be a bencher of his Inn, and the senior Q.C.'s and some of the senior juniors (you will know what I mean) will also be benchers. All lunch together on a basis of equality, whether judge, silk or junior. Seniority as a bencher depends on seniority of election, and is unaffected by judicial office. The atmosphere is one of ease and friendliness; and informal though this is, it has a constitutional importance. It is in these regular and informal contacts that we find so much of value rubbing off on each other. It tends to prevent the judges from becoming pompous and overbearing; and not only is the judge constantly reminded of his own days at the Bar, but also the silk or junior finds himself absorbing overtones of the Bench. A civilizing atmosphere spills over into the courts, and sweetens the acerbities of the contest. This association contributes towards a firmness of moral tone throughout the administration of the law, and provides a nursery for the future judge.

6. It is rare for an appointment to the High Court to be refused. The prevailing tone is that it is of paramount importance to the country that the standard of the Bench should be maintained at the highest possible level, and that if a barrister is offered an appointment to the Bench, this shows that the Lord Chancellor thinks him the most suitable person to be appointed. Whatever the individual feelings may be, the need to maintain the standard of the Bench impels acceptance. Money, of course, comes into it; but in the end it plays a small part. The basic philosophy may be put thus: money is of great importance to a man who is not earning enough to be free from worry about his finances. But when enough money is coming in to support a reasonable life, free from worry, money ceases to matter (though it may remain a thing of delight). What does matter is the kind of life you lead, the kind of work you do, whether you feel that what you are doing is useful work that you have some prospect of doing well, and yet is work that calls for everything that you have. Whatever being on the Bench may fail to do, it does do that; and this makes it all worth while. Going on the Bench may mean halving your income, or worse; but that matters little compared with the rewards, intangible though they may be. In any case, if I may sound a more mundane note, for most judges the end of the financial burdens of educating and launching their children in life has come or is in sight before appointment to the Bench.

7. Last, and in some ways the most important, is the fact that 25 years ago politics dropped almost completely out of appointment to the English Bench. The effect of political considerations in making judicial appointments is certainly not something to be exclusively attributed to Lord Halsbury while he was Lord Chancellor, interesting though some of his appointments were. Long before his time, and for many years after it, the general belief was that a career in Parliament was a powerful aid to appointment to the Bench; and there were many appointments that gave colour to this belief. The normal road to many of the highest offices in the law, too, was not by successful service as a puisne judge but by becoming Attorney-General or Solicitor-General. The Attorney-General of the day was regarded as having something of a right to the Chief Justiceship of the Common Pleas when it fell vacant. It was his "pillow", and when in 1880 that office in effect became merged in the Chief Justiceship of the Queen's Bench as the Lord Chief Justiceship of England, some regarded that office as having become the pillow. Later 
events tended to support that view; and although the emphasis on politics was probably lessening, down to the war of 1939-45 the position was substantially unaltered.

The change can almost be pinpointed. On January 21, 1946, Viscount Caldecote C. J., a former Solicitor-General, Attorney-General and Lord Chancellor, resigned, and Lord Goddard, a law lord, was appointed Chief Justice in his place. Lord Goddard was a lawyer through and through, with no more than a faint brush with politics in his youth; and he had moved steadily up from the King's Bench to the Court of Appeal and then to the House of Lords. Within a fortnight, on February 1, 1946, Sir Donald Somervell, a former Tory Attorney-General, was appointed to a seat in the Court of Appeal, even though the Government in power from 1945 to 1951 was a Labour government. These two appointments seem to have set the seal on the change. Politics were out, and such politics as were in were bi-partisan. During the six years of the Labour government, Lord Jowitt, as Lord Chancellor, was responsible for the appointment of over half the entire Bench; and yet not until towards the end of that time did he make any appointment to the High Court from the M.P.'s supporting his own party, and then only one. In 1958 Lord Goddard retired as Chief Justice, and despite political contenders, the appointment made was of Lord Parker, a Lord Justice with no political career. When Lord Parker retired this year, again the appointment as Chief Justice went to a non-political member of the Court of Appeal, Lord Widgery; and each of these appointments was made while a Tory government was in power. With that unanimity of performance, there is good reason to believe that each of the two major political parties is at least agreed on the proper approach to judicial appointment today.

I am not saying that to have been in politics is today an actual disqualification for appointment to the Bench; but I do say that to be an active supporter of the party in power no longer seems to be an asset of any real weight. Experience in public affairs, especially in Parliament, may be a factor of great value in moulding a man's character and giving him breadth of vision; the Bench would be the poorer without some who have this background. But it has ceased to matter much whether the candidate for appointment is a supporter or opponent of the party in power. With the withering of partisan claims to appointment has come another change. For over twenty years nearly all appointments to the Court of Appeal and House of Lords have been by way of promotion from the High Court, and not per saltum from the Bar. A vacancy in the Court of Appeal will be filled from the ranks of the High Court judges whose judicial abilities are known. No longer is there the problem of trying to guess the probable performance of a giant of the Bar as a Lord Justice of Appeal, and trying to compare that guess with a reasoned estimate, based on experience, of how a High Court judge of, say, five years standing would do in the Court of Appeal.

Those, then, are the seven factors that I wanted to put before you. Perhaps I may add some comments on two final matters. First, there is the actual process of appointment to the Bench. On this, I speak with no certain knowledge, but on guesses which I hope are intelligent. The Lord Chancellor's Office is in effect a small government department, with a staff of some two dozen lawyers. By a mysterious system of osmosis and grape-vines, I would expect the Lord Chancellor and his staff to have a pretty good idea about all that is going on in the legal world. If at any 
given moment you were to ask the Lord Chancellor whether $\mathrm{X}$ or $\mathrm{Y}$ or $\mathrm{Z}$ is likely to be appointed a judge when a vacancy occurs, and he were willing to answer, I should expect him to be able to say, then and there, that $\mathrm{X}$ is a strong candidate, that $\mathrm{Y}$ is a possible, and that $\mathrm{Z}$ is a nonstarter. You will remember how small the English Bar is, how few English silks there are, and how small the country is. Only a very small part of the population lives more than 250 miles from London.

Despite that background of knowledge of the Bar, the Lord Chancellor may be expected to consult the Chief Justice and the Master of The Rolls (who presides over the Court of Appeal) when a vacancy occurs; and if it is in the Chancery Division or the Probate, Divorce and Admiralty Division, he may well consult the head of that Division as well. Whether those consulted ever have or take the initiative, suggesting that $A$ or $B$ is better than $\mathrm{X}$ and $\mathrm{Y}$ who are under consideration, I cannot say. I should doubt if there are rules or even conventions; I should expect everything to be highly informal or, if you like, very English. When the Courts Act, 1971 , comes into force there will be many changes, some of them important; but I do not think that they will alter the essence of what I have been saying.

Secondly, perhaps I may be mildly historical. On at least some views it is possible to discern four stages in the part played by politics in appointments to the Bench, each stage merging into the next. In the first stage, party politics may play so large a part that some of those appointed fall short of the standards that the office demands. In the second stage, political claims do no more than give some preference amongst those who are fully qualified for appointment; of three candidates with not much to choose between them, the supporter of the party in power will be preferred to the political opponent or the politically inert. Without being unduly cynical, it is possible to observe that there are times when a government may prefer the sight of a political opponent sitting nonpolitically on the Bench to the sight of him in vigorous opposition in the legislature. The third stage comes when the political opponent has prospects of appointment which, other things being equal, are on a par with those of a political supporter, or nearly so. At the fourth stage politics have ceased to play any real part. Appointments are made very largely from the ranks of those who have made law and not politics their life.

As I have indicated, England seems to have reached this fourth stage in 1946. Where Canada is I must leave you to say; if I had to guess, from what I have read and heard recently my surmise would be that it is somewhere about the third stage, or not far short of it. I repeat that I would not suggest that politics should disqualify. In considering suitability for the Bench a strong case be made for the wide-ranging span of a statesman's career as against the restricted vision of a technically superb lawyer; the old jibe is that law sharpens the mind by narrowing it. But not all politicians are statesmen, nor do all fine lawyers have minds that are closed to the wider issues of life-not by a long chalk. In the end, the question, as in so many fields, is one of balance, within the national genius.

If as lawyers and citizens you think it of paramount importance to a civilized country to have a strong and independent Bench which justly commands the respect of all, you may well put your requirements under two main heads. First, there must be a determination that any vacant 
seat on the Bench will be offered to whoever seems the best qualified, with all that is relevant taken into account and all that is irrelevant discarded. Nothing less than the best will do. If that determination is to be effective, there must go with it a political strength sufficient to be able to resist pressures that would distort the determination. Once one political party has settled to this course, experience suggests that other parties will do no less. Second, anyone who is offered an appointment must feel a strong sense of obligation to accept it and serve out his term. Doubtless there will sometimes be overwhelming obstacles to acceptance; but without a sense of duty to serve in whatever capacity is offered, good choices will too often fail to result in good judges ascending the Bench.

I have taken too long, and said too little that will be of any value to you. So much of what I have said is tied to the English scene and done in an English way; and some of what we do is not for export. But in recent years much has changed in England, and even if I have said nothing of any value in Canada, I hope that I have at least set moving some trains of thought in what, for me, is a fascinating and important branch of the administration of the law. 